\title{
Pengaruh arah aliran input resin sintetis pada proses vacuum infusion resin terhadap kekuatan tarik komposit serat kulit waru (hibiscus tiliaceus)
}

\author{
Deky Framasta ${ }^{1}$, Akhmad Farid ${ }^{2}$, Nova R. Ismail ${ }^{3}$, Arief Rizki Fadhillah ${ }^{4}$ \\ 1,2,3,4Teknik Mesin, Fakultas Teknik, Universitas Widyagama Malang \\ Jalan borobudur No 35, Malang, Indonesia \\ ${ }^{*}$ Corresponding author: arief.rizki.f@widyagama.ac.id
}

\begin{abstract}
The use of natural fibers as a reinforcing material or reinforcement in composite materials has long been developed. Natural fibers are good environmentally materials in the development of engineering materials. Good environmentally materials are materials that, when used and disposed of, do not have the potential to damage the environment and harm health. Natural fibers have different characteristics and properties for each type. The bark fibers of the hibiscus tree (hibiscus tiliaceus) can also be seen as the characteristics of several factors that affect the tensile strength. This study aims to analyze the fault by knowing the direction of flow of synthetic resin input with the vacuum infusion resin method using the bark fiber of the hibiscus tree and bisphenol resin to tensile strength. The bark of the hibiscus tree was treated with 6\% NaOH immersion for 120 minutes. And variations in the direction of resin flow input 1 In 1 Out, 2 In 1 Out and 4 In 1 Out. The resin used is Bisphenol. The result of the tensile test is the variation of the flow direction of 2 In 1 Out, the highest tensile stress value is $328.18 \mathrm{MPa}$, the lowest tensile stress is the variation in the flow direction of 4 In 1 Out with a value of $271.17 \mathrm{MPa}$. The fault model of all variations in the flow direction is multiple areas, as well as fiber pull out in the 1 In 1 Out and 4 In 1 Out flow directions. For 2 In 1 Out delamination fault mode.
\end{abstract}

Keywords: Composite, hibiscus bark fiber, resin flow direction, vaccum infusion resin.

\begin{abstract}
Abstrak
Pemanfaatan serat alam (natural fiber) sebagai bahan penguat atau reinforcement pada bahan komposit telah lama dikembangkan. Serat alam merupakan bahan ramah lingkungan dalam pengembangan material teknik. Material ramah lingkungan adalah material yang pada saat digunakan dan dibuang tidak memiliki potensi merusak lingkungan dan mengganggu kesehatan. Serat alam memiliki karakteristik dan sifat yang berbeda setiap jenisnya. Serat kulit pohon waru (hibiscus tiliaceus) juga dapat dilihat karakteristik dari beberapa faktor yang mempengaruhi kekuatan tarik. Penelitian ini bertujuan untuk menganalisa patahan dengan mengetahui arah aliran input resin sintetis dengan metode vacuum infusion resin yang menggunakan serat kulit pohon waru dan resin bisphenol terhadap kekuatan tarik. Serat kulit pohon waru diberi perlakuan perendaman $\mathrm{NaOH}$ 6\% selama 120 menit. Dan variasi arah input aliran resin 1 In 1 Out, 2 In 1 Out dan 4 In 1 Out. Resin yang digunakan adalah Bisphenol. Hasil dari pengujian tarik adalah variasi arah aliran 2 In 1 Out nilai tegangan tarik tertinggi 328,18 MPa, tegangan tarik terendah pada variasi arah aliran 4 In 1 Out dengan nilai 271,17 MPa. Model patahan seluruh variasi arah aliran adalah multiple area, serta fiber pull out pada variasi arah aliran 1 In 1 Out dan 4 In 1 Out. Untuk 2 In 1 Out mode patahan delaminasi.
\end{abstract}

Kata kunci: Komposit, serat kulit pohon waru, arah aliran resin, vaccum infusion resin. 


\section{Pendahuluan}

Pemanfaatan serat alam (natural fiber) sebagai bahan penguat atau reinforcement pada bahan komposit telah lama dikembangkan. Serat alam merupakan bahan ramah lingkungan dalam pengembangan material teknik. Material ramah lingkungan adalah material yang pada saat digunakan dan dibuang tidak memiliki potensi merusak lingkungan dan mengganggu kesehatan. Serat alam adalah serat yang dihasilkan dari hewan atau tumbuh-tumbuhan. Serat dari hewan dihasilkan dari kulit dan bulu. Serat dari tumbuh-tumbuhan dihasilkan dari biji, kulit, dan daun. Salah satu tanaman yang menghasilkan serat dari kulitnya adalah pohon waru. Pemanfaatan serat alam sebagai penguat komposit merupakan salah satu alternatif untuk mengembangkan material ramah lingkungan dengan syarat tetap menjaga ekosistem bahan baku serat tersebut [1][2].

Material komposit adalah material yang tersusun atas dua campuran atau lebih material dengan sifat kimia dan fisika berbeda, dan menghasilkan sebuah material baru yang memiliki sifat-sifat berbeda dengan material -material penyusunnya. Dewasa ini pemanfaatan material komposit semakin meningkat, seiring dengan pemakaian komposit mulai dari yang sederhana sampai ke bentuk yang rumit seperti alat-alat rumah tangga sampai sektor industri baik dari skala kecil ataupun skala besar [3].

Adapun keunggulan serat alam yang dimanfaatkan sebagai reinforcement, antara lain: ringan, kuat, ramah lingkungan dan ekonomis. Beberapa serat alam yang digunakan sebagai reinforcement antara lain: enceng gondok, ampas tebu, kapas, serat rami dan serat kulit pohon waru. Komposit terdiri dari matrik dan penguat, matrik berfungsi sebagai pengisi sedangkan bahan penguat berfungsi menguatkan komposit tersebut. Serat kulit pohon waru berpotensi sangat baik sebagai reinforced pada komposit serat alam, akan tetapi perlu adanya pengembangan penelitian mengenai jenis matrik yang digunakan pada komposit sehingga akan menghasilkan ikatan antar serat dan matrik yang lebih baik [4]. Salah satu penggunaan serat alam untuk material komposit yaitu serat kulit pohon waru (hibiscus tiliaceus). Pohon waru adalah tanaman yang mengandung banyak serat di dalamnya terutama pada kulit batangnya. Pohon waru ini mudah ditemukan di negara Indonesia karena mudah tumbuh dan penyebarannya yang luas. Pohon waru memiliki tinggi sekitar 5 sampai 15 meter, warnanya coklat, batang berkayu, bercabang, bulat, kayu terasnya agak ringan, cukup padat, berstruktur cukup halus dan tidak begitu keras, liat dan awet bertahan dalam tanah.

Tahun 2017 telah dilakukan penelitian komposit serat kulit pohon waru. Material penguat untuk komposit menggunakan serat kulit pohon waru yang dapat digunakan sebagai reinforcement dalam komposit. Komposit berpenguat kulit pohon waru kontinyu laminat dengan perlakuan alkali $\mathrm{NaOH}$ sebesar $6 \%$ selama 120 menit. Penelitian ini menggunakan variasi jenis resin, antara lain : polyester BTQN 157, bisphenol A LP - 1Q - EX, ripoxy R- 802 dan epoxy. Rasio fraksi massa antara serat dan fiber adalah 60: 40. Komposit menggunakan metode Vacuum Bagging dengan tekanan mencapai -27 atm. Dari penelitian tersebut diketahui bahwa regangan maksimum resin poliester, resin bisphenol dan resin ripoksi masing-masing adalah sebesar $0.0233 \mathrm{~mm} / \mathrm{mm}, 0.0318$ $\mathrm{mm} / \mathrm{mm}$ dan $0.0241 \mathrm{~mm} / \mathrm{mm}$. Resin epoksi menghasilkan regangan maksimum sebesar $0.0271 \mathrm{~mm} / \mathrm{mm}$. Komposit dengan regangan maksimum tertinggi terdapat pada komposit dengan resin bispheol, sedangkan regangan maksimum terendah terdapat pada komposit dengan resin Poliester. Jadi berdasarkan hasil kekuatan tarik dan regangan maksimum di atas, maka dapat diketahui bahwa komposit serat kulit pohon waru dengan resin bisphenol memiliki kekuatan tarik dan regangan maksimum tertinggi, sedangkan yang terendah adalah komposit dengan resin poliester. Hal ini 
dikarenakan, resin bisphenol memiliki sifat lentur dan mulur yang menjadikan regangan dan kuat tarik akan lebih tinggi serta ikatan yang dihasilkan antara matrik bisphenol dan serat waru lebih baik daripada resin lainnya. Dan untuk analisa patahan hasil uji tarik diketahui bahwa patahan yang terjadi pada seluruh variasi jenis resin tidak terjadi patahan yang terpusat pada satu titik atau tidak dapat diprediksi posisi patahan kecuali patahan dengan resin Epoksi $\mathrm{A}$ dan $\mathrm{B}$ yang memiliki fracture area lebih kecil [5].

Fauzi di tahun 2017 melakukan penelitian pengaruh tekanan vacuum terhadap kekuatan Tarik dan kekuatan lentur pada biokomposit serat purun tikus (eleocharis dulcis). Proses biokomposit menggunakan metode laminat dalam kondisi vacuum dan memvariasikan tekanannya agar mendapatkan tekanan yang optimum. Metode vacuum digunakan untuk meningkatkan kekuatan mekanik dan mencegah gelembung udara pada resin (void). Void dihindari karena dapat mengurangi kekuatan material tersebut, sehingga aliran matriks untuk membasahi serat berjalan dengan baik dan udara yang terjebak dapat dikeluarkan karena adanya proses vacuum. Hasil dari penelitian tersebut dimana kekuatan tarik maksimum tertinggi terjadi pada tekanan vacuum 26 cmHG dengan 54,7 MPa dan kekuatan tarik terendah terjadi di tekanan $76 \mathrm{cmHg}$ dengan harga 41,6 MPa [3].

Setiaji (2016) meneliti tekanan dan waktu pengerasan komposit memberikan pengaruh terhadap nilai kekasaran permukaan. Untuk mengetahui perbedaan tekanan vacuum pada proses pembuatan komposit dan waktu pada proses pengerasan komposit Metode Vacuum Assited Resin Infunsion (VARI) dengan matrik polyester berpenguat serat fiber glass terhadap pengujian kekasaran permukaan, kekuatan tarik dan impact pada benda uji. Penelitian ini mampu mengoptimalkan waktu pengerasan komposit dan tekanan pada proses VARI dan mendapatkan kekuatan yang tinggi dan kekasaran permukaan yang rendah. Dari hasil pengujian kekasaran permukaan, pengujian tarik dan pengujian impact di peroleh pengaruh tekanan vacuum pada proses VARI yaitu, semakin rendah tekanan vacuum yang digunakan maka menurunkan sifat fisik (semakin halus) komposit dan meningkatkan sifat mekanik komposit. Hasil yang didapat pada variasi tekanan yang dilakukan: (1) Tekanan vacuum 0,2 bar menghasilkan nilai kekasaran permukaan $0,498 \mu \mathrm{m}$, nilai kekuatan tarik 27,344 $\mathrm{MPa}$ dan nilai kekuatan impact $47,859 \mathrm{~J} / \mathrm{mm}^{2}$, tekanan vacuum 0,5 bar menghasilkan nilai kekasaran permukaan $0,544 \mu \mathrm{m}$, nilai kekuatan tarik $15,664 \mathrm{MPa}$ dan nilai kekuatan impact 39,953 J/mm² dan tekanan vacuum 1,0 bar menghasilkan nilai kekasaran permukaan $0,577 \mu \mathrm{m}$, nilai kekuatan tarik $14,768 \mathrm{MPa}$ dan nilai kekuatan impact $33,338 \mathrm{~J} / \mathrm{mm}^{2}$. (2) Dari hasil pengujian kekasaran permukaan, pengujian tarik dan pengujian impact diperoleh pengaruh pengerasan komposit pada proses VARI yaitu, semakin cepat proses pengerasan komposit yang dilakukan maka menurunkan sifat fisik (semakin halus) komposit dan meningkatkan sifat mekanik komposit. Hasil yang didapat pada variasi pengerasan komposit yang dilakukan: waktu pengerasan komposit selama 2 jam menghasilkan nilai kekasaran permukaan $0,498 \mu \mathrm{m}$, nilai kekuatan tarik 27,344 $\mathrm{MPa}$ dan nilai kekuatan impact $47,859 \mathrm{~J} / \mathrm{mm}^{2}$, waktu pengerasan komposit selama 4 jam menghasilkan nilai kekasaran permukaan $0,544 \mu \mathrm{m}$, nilai kekuatan tarik 15,664 $\mathrm{MPa}$ dan nilai kekuatan impact $39,953 \mathrm{~J} / \mathrm{mm}^{2}$ dan waktu pengerasan komposit selama 6 jam menghasilkan nilai kekasaran permukaan $0,577 \mu \mathrm{m}$, nilai kekuatan tarik $14,768 \mathrm{MPa}$ dan nilai kekuatan impact $33,338 \mathrm{~J} / \mathrm{mm}^{2}$ [6].

Dari beberapa penelitian di atas, maka dapat dilihat bahwa serat kulit pohon waru (hibiscus tiliaceus) dapat digunakan sebagai reinforcement pada komposit. Serat alam memiliki karakteristik dan sifat yang 
berbeda setiap jenisnya. Serat kulit pohon waru (hibiscus tiliaceus) juga dapat dilihat karakteristik dari beberapa faktor yang mempengaruhi kekuatan tarik, antara lain: konsentrasi alkali $\mathrm{NaOH}$, jenis resin sintetis dan model serat. Tetapi dari beberapa penelitian di atas belum dibahas tentang arah aliran resin yang dipakai untuk pembuatan spesimen. Dengan demikian penelitian ini bertujuan untuk mengetahui pengaruh arah aliran input resin sintetis pada proses vacuum infusion resin terhadap kekuatan tarik komposit serat kulit waru (hibiscus tiliaceus).

\section{Metode Penelitian}

\section{Variabel penelitian}

Variabel bebas adalah variabel yang dipilih oleh peneliti. Variabel yang digunakan adalah arah aliran resin 14 In 1 Out, 2 In 1 Out dan 4 In 1 Out. Adapun arah aliran resin sebagai berikut:

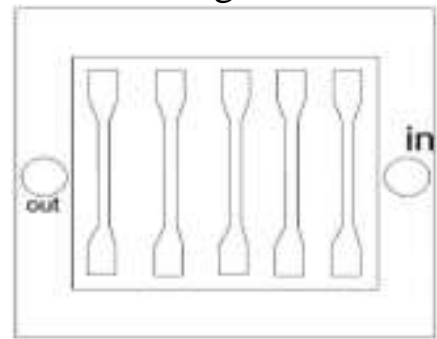

(a)

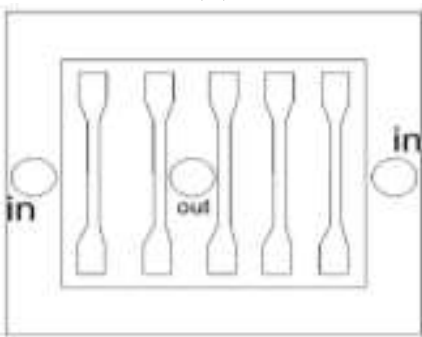

(b)

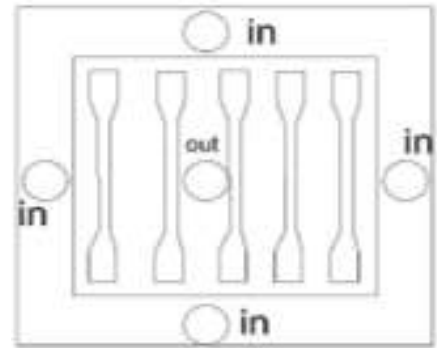

(c)

Gambar 1. Arah aliran resin (a) 1 In 1 Out (b) 2 In 1 Out (c) 4 In 1 Out
Variabel terikat pada penelitian ini yaitu: tegangan, regangan dan patahan Variabel terkontrol

a. Struktur serat disusun continue searah dengan beban tarik.

b. Komposit menggunakan fraksi massa Serat 60 : Resin 40.

c. Uji tarik komposit menggunakan standar ASTM D638-03 Type I [7-10].

d. Resin bisphenol dengan komposisi Resin 100 gram; Prometer 0,8 gram; Mixpo 0,4 gram.

e. Menggunakan serat kulit pohon waru (hibiscus Tiliaceus).

f. Komposisi perlakuan alkali $\mathrm{NaOH} 6 \%$ Aquades 938,8 gram x $2 ; \mathrm{NaOH} 61,2$ gram x 2 .

g. Metode manufactur komposit mengunakan metode Vaccum Infusion Resin.

h. Jumlah laminat dalam satu spasimen adalah 22 lembar.

2. Diagram alir penelitian

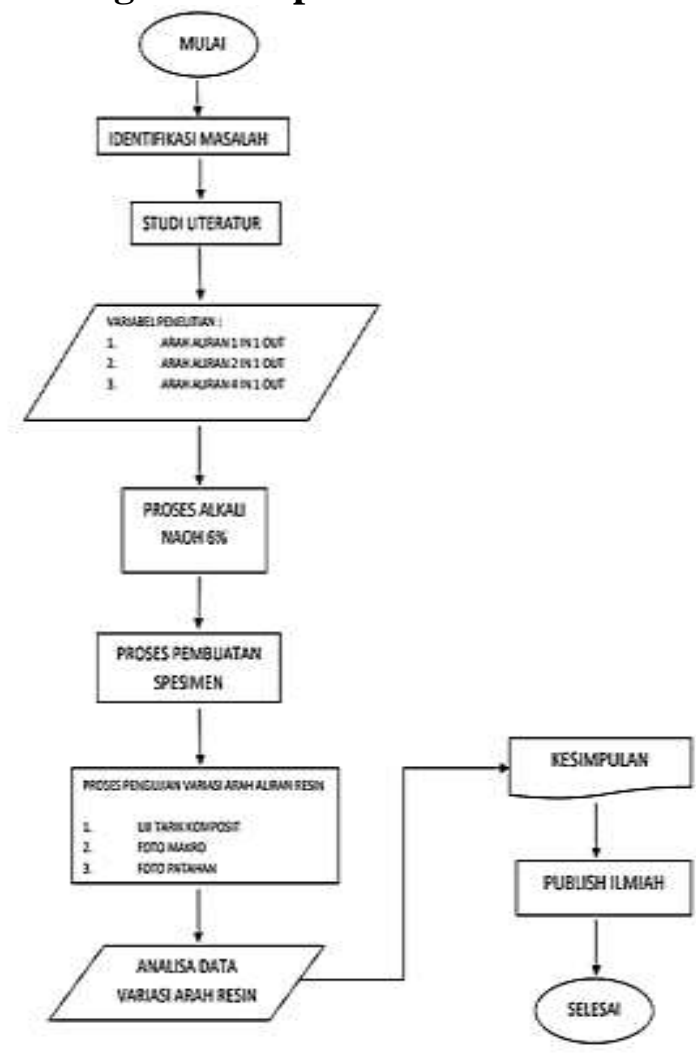

Gambar 2. Diagram Alir Penelitian 


\section{Hasil dan Pembahasan}

1. Pengaruh variasi input aliran resin pada vaccum infusion resin terhadap tensile strenght komposit serat kulit pohon waru

Berdasarkan data pengujian, didapatkan rata-rata tensile strength setiap variasi arah aliran input resin seperti di bawah ini :

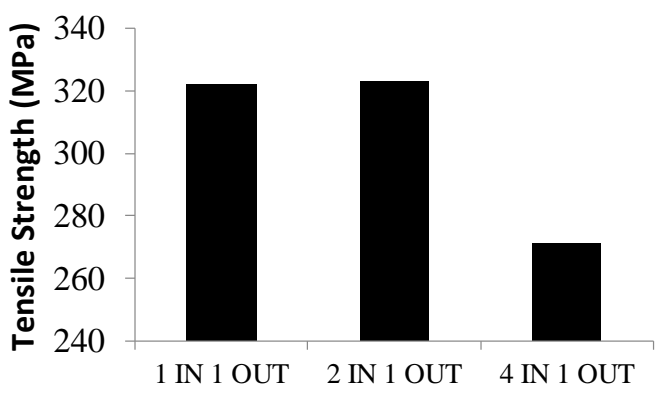

Variasi Aliran Input Resin

Gambar 3. Tensile strength komposit serat kulit waru variasi arah aliran

Pada gambar 3, komposit serat kulit pohon waru dengan variasi arah aliran resin 1 In 1 Out memiliki tegangan tarik sebesar 322,25 MPa. Komposit serat kulit pohon waru dengan variasi arah aliran resin 2 In 1 Out memiliki tegangan tarik sebesar 323,18 MPa. Komposit serat kulit pohon waru dengan variasi debit aliran resin 4 In 1 Out memiliki tegangan tarik sebesar 284,54 MPa.

Dari hasil tegangan tarik rata-rata setiap variasi di atas dapat diketahui bahwa arah aliran resin pada metode vacuum infusion resin mempengaruhi tegangan tarik komposit. Hal tersebut dapat dilihat dari tegangan tarik dengan variasi arah aliran tertinggi pada arah aliran 2 In 1 Out, sedangkan tegangan terendah pada arah aliran 4 In 1 Out. Hal ini diduga pada arah aliran resin 4 In 1 Out, pembagian aliran resin yang tidak merata. Hal tersebut diduga karena dua selang input aliran resin dalam satu wadah sehingga pembagian resin pada saat manufaktur spesimen tidak merata sehingga menyebabkan tegangan tarik menjadi rendah.
2. Pengaruh variasi input aliran resin pada vaccum infusion resin terhadap regangan komposit serat kulit pohon waru

Berdasarkan data pengujian, didapatkan rata-rata tensile strength setiap variasi arah aliran input resin seperti Gambar 4.

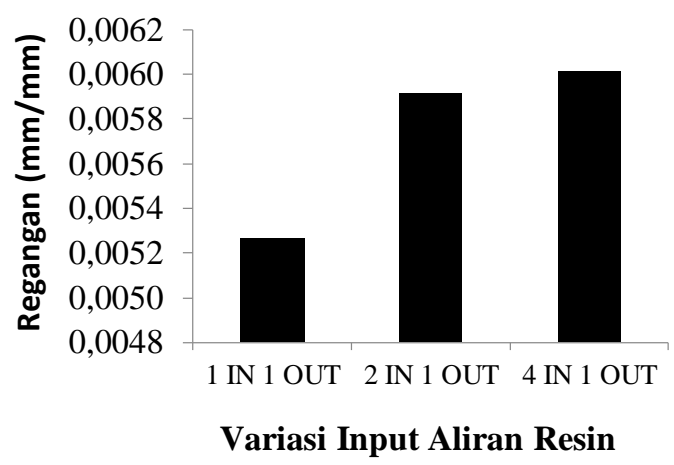

Gambar 4. Regangan komposit serat kulit waru Variasi Arah Aliran

Pada Gambar 4 menunjukkan komposit serat kulit pohon waru dengan variasi arah aliran resin 1 In 1 Out memiliki regangan tarik sebesar $0,0052 \mathrm{~mm} / \mathrm{mm}$. Komposit serat kulit pohon waru dengan variasi arah aliran resin 2 In 1 Out memiliki regangan tarik sebesar $0,0059 \mathrm{~mm} / \mathrm{mm}$. Komposit serat kulit pohon waru dengan variasi arah aliran resin 4 In 1 Out memiliki regangan tarik sebesar $0,0060 \mathrm{~mm} / \mathrm{mm}$.

Dari hasil regangan tarik rata-rata setiap variasi di atas bisa diketahui bahwa debit aliran resin pada metode vacuum infusion resin mempengaruhi regangan tarik komposit. Hal ini bisa dilihat bahwa regangan komposit serat kulit pohon waru dengan variasi arah aliran 4 In 1 Out memiliki regangan tertinggi dan komposit dengan arah aliran 1 In 1 Out memiliki regangan terendah.

3. Analisa patahan komposit serat kulit waru (hibiscus tiliaceus) variasi arah aliran

Berdasarkan pengujian tarik komposit serat kulit waru variasi arah aliran yang telah dilakukan maka patahan yang terjadi pada masing-masing spesimen variasi adalah sebagai berikut : 


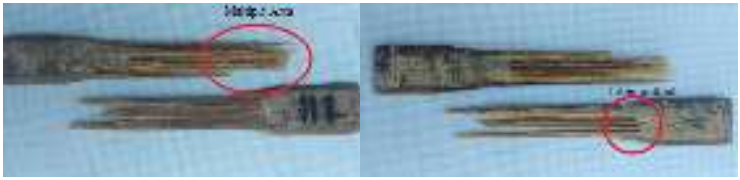

(a)

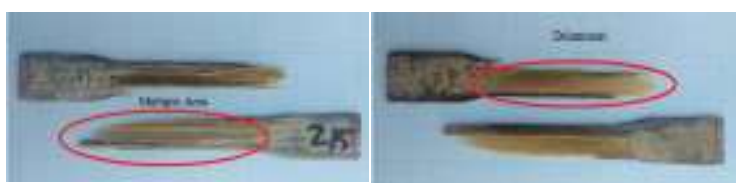

(b)

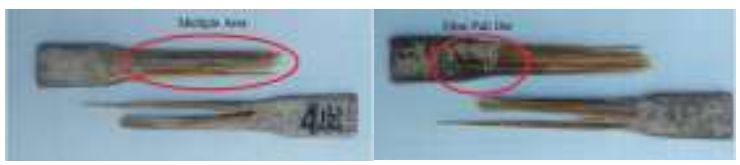

(c)

Gambar 5. Foto Makro Patahan Komposit Serat

Kulit Waru (Hibiscus Tiliaceus), (a) arah aliran resin 1 In 1 Out, (b) arah aliran 2 In 1 Out, (c) arah aliran resin 4 In 1 Out.

Foto patahan pengujian tarik komposit serat kulit waru dengan variasi arah aliran resin pada gambar 5, menunjukkan bahwa seluruh variasi arah input aliran tidak terjadi patahan yang terpusat pada satu titik. Selain itu, patahan yang terjadi mengikuti arah orientasi serat unidirectional. Patahan komposit pada semua variasi arah aliran didominasi oleh multiple area, hal ini membuktikan terjadinya ikatan yang merata antar resin dan serat. Untuk patahan pada variasi arah input aliran resin 1 In 1 Out dan 4 In 1 Out adalah patah getas atau brittle serta mengalami fiber pull out, yaitu ikatan antara serat dan metriks tidak kuat. Terlihat dari bentuk patahan yang tercabut. Sedangkan pada arah input aliran 2 In 1 Out model patahan adalah delaminasi, hal ini terlihat karena terkelupasnya lapisan tipis permukaan pada specimen.
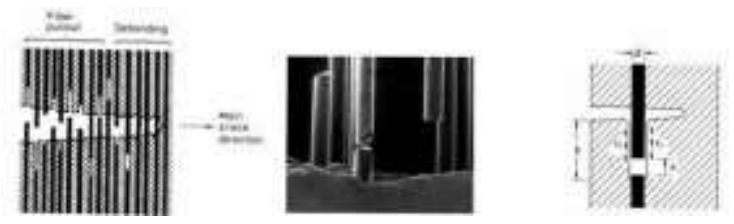

(a)
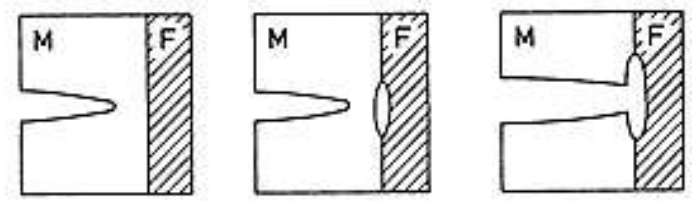

(b)

Gambar 6. Ilustrasi Model Patahan (a). Fiber Pull Out, (b). Delaminasi

\section{Kesimpulan}

Kekuatan tarik tertinggi pada variasi arah aliran 2 In 1 Out memiliki rata-rata kekuatan tarik sebesar 328,18 MPa sedikit lebih tinggi dari variasi arah aliran 1 In 1 Out yaitu sebesar 322,25 Mpa. Sedangkan variasi arah aliran 4 In 1 Out memiliki kekuatan tarik terendah sebesar 271,17 MPa. Variasi arah aliran 2 IN 1 OUT memiliki rata-rata regangan tertinggi sebesar $0,0061 \mathrm{~mm} / \mathrm{mm}$ sedikit lebih besar dibandingkan variasi arah aliran 1 In 1 Out dan 2 In 1 Out dengan nilai rata-rata sebesar $0,0060 \mathrm{~mm} / \mathrm{mm}$. Patahan untuk semua variasi arah aliran didominasi patahan multiple area. Variasi arah aliran 1 In 1 Out dan 4 In 1 Out menunjukkan patah getas atau brittle serta fiber pull out. Model patahan variasi arah aliran 2 In 1 Out adalah model patahan delaminasi.

\section{Referensi}

[1] Prasetyo, A., Purwanto, H., \& Respati, S. M. B. (2016). Pengaruh waktu perendaman serat kulit pohon waru (Hibiscus Tiliaceus) pada air laut terhadap struktur mikro dan kekuatan tarik. JURNAL ILMIAH MOMENTUM, 12(2).

[2] Fadhillah, A. R. (2017). Desain Pola Fiber Berbahan Serat Kulit Pohon Waru (Hibiscus Tiliaceus) Bermatrik Resin Sintetis Terhadap Kekuatan Tarik Komposit

[3] Fauzi, Y. R., Sonief, A. A., \& Suprapto, W. (2017). Pengaruh Tekanan Vacuum terhadap Kekuatan Tarik dan Kekuatan Lentur pada Biokomposit Serat Purun Tikus 
(Eleocharis Dulcis). Rekayasa Mesin, 7(3), 129-134.

[4] Fadhillah, A. R., Hermawan, D., \& Wardhani, A. R. (2019). Pengaruh prosentase larutan $\mathrm{NaOH}$ pada proses alkalisasi serat kulit pohon waru (hibiscus tiliaceus) sebagai reinforcement komposit terhadap kekuatan tarik serat tunggal. Turbo: Jurnal Program Studi Teknik Mesin, $8(2)$.

[5] Fadhillah, A. R., Setiyabudi, S. A., \& Purnowidodo, A. (2017). Karakteristik komposit serat kulit pohon waru (Hibiscus Tiliaceus) berdasarkan jenis resin sintetis terhadap kekuatan tarik dan patahan komposit. Rekayasa Mesin, 8(2), 101-108.

[6] Setiaji, B. T., \& Arief, D. (2016). Optimasi Parameter Proses Vacuum Assisted Resin Infusion Terhadap Sifat Fisik dan Mekanik Komposit Polyester Fiber Glass.

[7] ASTM Internasional. (n.d.). Standard Test Method for Tensile Properties of Plastics D683-03. United State.

[8] Budiyanto, E., Nugroho, E., \& Masruri, A. (2017). Pengaruh diameter filler dan arus pada pengelasan TIG terhadap kekuatan tarik dan struktur mikro pada baja karbon rendah. Turbo: Jurnal Program Studi Teknik Mesin, 6(1).

[9] Budiyanto, Eko; Eko Nugroho, Asroni, Kiki Septiadi. 2019. Experimental evaluation of mechanical properties of gmaw welded pipes. Prosiding SNTTM XVIII, Jakarta 9-10 September 2019.

[10] Budiyanto, Eko. 2020. Pengujian Material. Metro: Laduny Alifatama. 